\title{
The Influence of Leadership on Employee Performance with Organizational Culture and Work Motivation as Intervening Variables
}

\author{
MACHDALENA AGUSTIN FITRIASARI ${ }^{1}$ \\ Malangkucecwara School of Economics \\ Malang, Indonesia \\ Email: nauracantik14@yahoo.co.id
}

HANIF MAULUDIN ${ }^{2}$

Lecturer, Malangkucecwara School of Economics

Malang, Indonesia

Email: hanifmauludin@gmail.com

DOI: 10.31364/SCIRJ/v6.i7.2018.P0718542

http://dx.doi.org/10.31364/SCIRJ/v6.i7.2018.P0718542

\begin{abstract}
The purpose of this research is testingand analyzing the influence of leadership on employee performance through organizational culture and work motivation. Population and sample consist of State Civil Apparatus in Government of Pasuruan regency at Integrated Service and Investment Service and the Regional Finance Board were 130 respondents. Data analysis method used is path analysis processed with software Smart Partial Least Square (PLS). The result of hypothesis testing found that 1) leadership did not directly influence toward employee performance, 2) leadership positively influence toward organizational culture, 3) leadership positively influence toward work motivation 4) leadership positively influence toward performance through organizational culture 5 ) leadership positively influence toward performance through work motivation. The results of this research are expected to be a source of information and consideration materials for the Leader on the Local Government Environment Pasuruan to more increasing the application of organizational culture and work motivation better with the result that can improve on employee performance.
\end{abstract}

Keywords: leadership, employee performance, organizational culture, work motivation.

\section{INTRODUCTION}

Strategy for the development of the region's current economic potential must be made on the basis of the opportunities and potentials of a region with presenting advantages possessed by a region and the local government policies that are friendly toward the business world. When the government has good and professional management, it will certainly have a positive impact on the economy in the region. For instance, more increasing the number of new businesses established, it will more easily absorb labor, increasing the local revenue, and also the increasing of the rregional economic index.

Responding to this that a reliable leader must be able to adapt the organization both internal and external environment. In this case, the organization is the Regional Government Organization. The demands of change morale will encourage organizations to work more efficiently and optimize their resources.

According to Timpe (1987: 65) "Leadership is a higher ability of management because a leader is strategist skill who set organizational goals both internal and external and aligning organizational assets and skills with opportunities and risks confronted by the environment".

An organization is formed to achieve a certain goal, the success of an organization is shown by its ability to achieve the set goals. The success of the organization in achieving the goals is largely determined by the performance of the organization that is strongly influenced by internal and external factors. External factors influence the organization is demographic, social, economic, and political growth. While the internal factors influence of the organization which except support external factor is a human resource in the organization (Wibowo, 2010).

An organization to achieve the objectives needs a carrying capacity in the form of four pillars, namely quality human resources, systems, integrated technology, appropriate strategies and adequate logistics. In the operational context of sustainable organizations that the role of human resources has a prime position. It is based on a thought that human resources 
as the main element in running the organization (Santoso, 2005). Human resources have an important role in moving the organization to achieve goals.

Motivation is a process to explain the intensity, direction, and perseverance of individual efforts to achieve a goal, especially organizational goals (Heneman et al., Igalens and Roussel, 1999). According to Yuli (2005: 142) that work motivation is an influential condition to generate and direct behavior related to work environment. For example motivation is a very important role in work. In addition, a highly motivated will make easier to implement with all his might, so that they got a gift as what theyparticipated and the easier to achieve success. One of increasing the work motivating at Pasuruan Regency Government is the incentive given to employees in accordance with the percentage of locally-generated revenue target achievement each year.But according to Regent Regulation No. 38 of 2016 on Supplementary Income of Regional Officials in the Government of Pasuruan Regency applied Supplementary Income of Regional Officials, while to obtain Supplementary Income of Regional Officials is enough with the attendance of the employee. Moreoverto achieve of Income of Regional Officials targets is not the main goal in obtaining additional income by employees. Indirectly it is quite influential in the performance of employees if not all employees have the same orientation in achieve of the vision and the mission.

Based on the formulation of research problems that have been described before, the purpose of this research is testing and analyzing the influence of leadership, organizational culture and work motivation on employee performance at the Government of Pasuruan.

\section{THEORITICAL REVIEW}

\section{Leadership}

According to Dubrin (2005), Siagian (2002), Nimran (2004) and Robbins (1996) in Ida (2008) that leadership is one's ability to influence others with his/her wayto cause others acting or responding towards the achievement of goals.

Leadership is a very important factor to influence the achievement of the organization because leadership is the main activity with the achievement of organizational goals. In general, leadership is defined as a process influencing the activities of individuals or groups to achieve goals in certain situations (Indriyo, 1997: 128).

\section{Organizational culture}

Organizational culture is the norm, values, assumptions, beliefs, philosophy, organizational habits, etc (the content of organizational culture) developed over a long period by founders, leaders, and members of the organization socialized and taught to new members and applied in organizations that influence the mindset, attitude, and behavior of members of the organization in producing products, serving consumers, and achieving organizational goals (Wirawan, 2007). Organizational culture is a philosophy that underlies organizational policies, rules of the association, and the feelings or climate brought about by the physical preparation of the organization (Vecchio, 1995).

\section{Work motivation}

Motivation is beginning process with a lack of physiological or psychological needs in the form of behavioral activity or encouraging intent in purpose or stimulant. Motivation is an effort undertaken by an organization to know and improve the willingness of work by a worker, it affected that they behave as they do in the organization (George and Jones, 2002).

Motivation is one factor that also has a very important role in improving productivity and employee performance. This is based on assumptions: (1) individuals have varying awareness, complex goals and competitive feelings, (2) most individual behaviors are consciously and purpose-directed and (3) individuals react, evaluate and has to feel toward their behavior outcome. (Lawer, 1994).

\section{Performance}

Performance is a description of the level of achievement of the implementation of an activity / program, the policy in realizing the goals, objectives, vision and mission of the organization contained in strategic planning of an organization (Bernad \& Russel, 1993; Vroom (in As'ad, 1999), Tika, 2006, Mahsun, 2006)

Armstrong (2004) that emphasized that performance is the result done by employees in a certain period of time, these results like goods and services or ability and behavior doing in the job. Furthermore, Mulyadi (2002) statement is employee performance is how a person engages in everything related to a job, position, or role in the organization.

Performance appraisal defined a procedure that includes setting performance standards, assessing the actual performance of employees in relation to performance standards, assessing the actual performance of employees in relation to standard work, and providing feedback to employees in order to motivate these employees to eliminate deterioration or continue to perform higher (Dessler, 2004).

According to Dharma (1995), things that need to be measured in employee performance appraisal include three things:

1. Quantity, which depends on the quantity produced;

2. Quality, which depends on the quality produced;

3. Timeliness, which depends on whether or not the planned time is appropriate. 


\section{Research Framework}

The research framework is a concept that describes the relationship pattern of all research activities to provide answers to the questions posed in the problem formulation. The research framework used in this research is directed toward the influence of Leadership on Employee Performance through Organizational Culture and Motivation.

Based on the theorized, it can be derived conception and hypothesis model as follows.

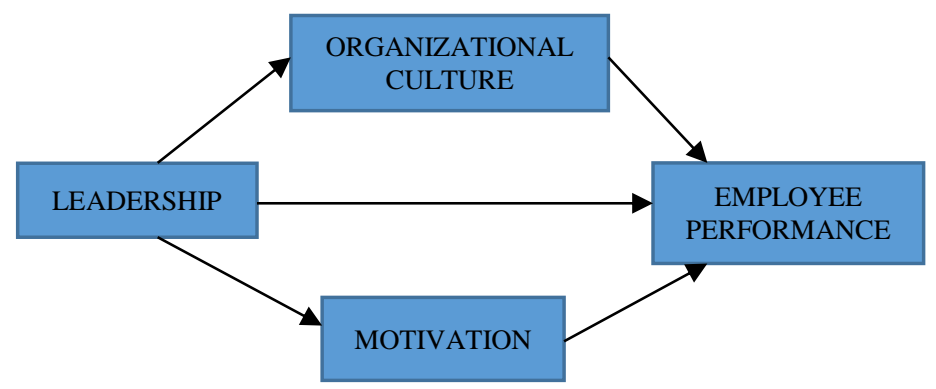

\section{Research Hypothesis:}

Based on the above framework, the research hypothesis formulated and tested the truth in this research are:

$\mathrm{H} 1$ : leadership influence to employee performance

$\mathrm{H} 2$ : leadership influenceto organizational culture

H3: leadership influence to motivation

H4: leadership influence to employee performance through organizational culture

H5: There is a significant influence between leadership on employee performance through motivation.

\section{RESEARCH METHODOLOGY}

\section{Types of research}

This research used quantitative methods supported by qualitative descriptive analysis. In this case, the authors will prove the hypothesis that has been formulated previously and make calculation analysis based on existing data and description systematically, factually and accurately about the facts, properties and relations between phenomenon under the research

\section{Method of collecting data}

This research is a survey research where the collection tool is a questionnaire. In this research the questionnaires were distributed to State Civil Apparatus at the Department of Investment and Integrated Service Pasuruan District and Regional Finance Board Pasuruan. The qquestionnaire is a method to collect primary data by using a set of questionnaires about variables measured through careful planning, arranged and packed in such a way that the answers of all questions can really describe the actual state of variables.

\section{Population and Sample}

The population is all State Civil Apparatus in Pasuruan District Integrated Service and Service Office ware forty-one persons and District Finance Board of Pasuruan Regency ware eighty-nine persons. This research uses census technique (Singarimbun and Effendi, 2008: 151) meaning that all the population used as research subject based on precision that becomes absolute because the value of estimation is equal to the parameter value, where the indicator degree of indicator from the high population.

\section{Research variable}

Variables in this study include:

a. Independent Variable / Independent Variables In this research, the variable independent is Leadership (X). The indicators used adopt from Susanto (2010) as follows: discipline, exemplary, firmness, openness, justice.

b. Variable Between / Intervening

In this research there are 2 (two) variables that become an intermediate / intervening variable that is:

1) Organizational culture (Z1) used the indicators adopt by Susanto (2010) are as follows: creative, perseverance, cooperation, integrity, rational.

2) Work motivation (Z2) used the indicators adopt by Susanto (2010) are as follows: spirit, career, work performance, appreciated, learning opportunities.

c. Dependent Variable / Dependent Variables

In this research, the dependent variable is Employee Performance (Y). The indicators used adopt from Susanto (2010) as follows: job target, responsibility, quantity, and quality of work, honesty, loyalty.

\section{Analysis Method}

In the research toobtain a predefined category assessment, the respondents are arranged into a tabulation of data which is then processed and presented in a tabulation of the frequency distribution. In addition, it would be analyzed using partial least square / PLS program. Tabulation data is used to describe and to interpret responses from respondents to each variable. Then to get the result of how big influence of leadership and work culture with motivation as an intervening variable to employee performance, can be done calculation or data processing by using partial least square / PLS program.

\section{RESEARCH RESULT AND DISCUSSION}

\section{Background of Respondents}

The total population were 130 respondents and all the questionnaires were re-received by the researchers. Characteristics of respondents by gender, age, last education and years of service can be explained in table 4.1 below:. 
Table 1. Characteristics of respondents

\begin{tabular}{|l|l|l|}
\hline Information & Total & Percentage \\
\hline Age & & \\
<35 years & 20 & $15,38 \%$ \\
36 - 45 Years & 52 & $40 \%$ \\
46 - 50 Years & 28 & $21,54 \%$ \\
>51 Years & 30 & $23,08 \%$ \\
& & \\
Total & $\mathbf{1 3 0}$ & $\mathbf{1 0 0 \%}$ \\
\hline Gender & & \\
Men & 70 & $53,85 \%$ \\
Women & 60 & $46,15 \%$ \\
Total & $\mathbf{1 3 0}$ & $\mathbf{1 0 0 \%}$ \\
\hline The Last Educations & & \\
Junior High School & 42 & $32,31 \%$ \\
Diploma & 10 & $7,69 \%$ \\
Bachelor (S1) & 52 & $40 \%$ \\
Post Graduate (S2/S3) & 26 & $20 \%$ \\
Total & $\mathbf{1 3 0}$ & $\mathbf{1 0 0 \%}$ \\
\hline Years of Service & & \\
1 - 10 Years & 48 & $36,92 \%$ \\
11 - 20 Years & 41 & $31,55 \%$ \\
21 -30 Years & 34 & $26,15 \%$ \\
>31 Years & 7 & $5,38 \%$ \\
Total & $\mathbf{1 3 0}$ & $\mathbf{1 0 0 \%}$ \\
\hline
\end{tabular}

Source: primary data, processed 2018

Based on the characteristics of the respondents above shows that employee in the Office of Investment and Integrated Services Pasuruan District and Regional Finance Agency Pasuruan dominated by young age with a long working period. Where young age is identically about their spirit and high motivation and has ideas of innovation for the organization in achieving organizational goals. It is also presenting that the number of male and female employees of equal proportion indicates no different treatment between men and women and has equal rights and opportunities in both job and selfdevelopment tasks. From the table also shows that the education owned by employees at the Department of Investment and Integrated Service Pasuruan District and Regional Finance Agency of Pasuruan is anacademician degree-holder, this is due to recruitment of more employees from academician degree-holder. Global challenges and public demand for government services are increasingly high so that the need for superior human resources and competent in dealing with demands and improving the quality of public services provided to the community.

\section{Hypothesis testing}

Hypothesis testing is done by looking at the inner value of the resulting model as shown in Figures 1 and Table 2

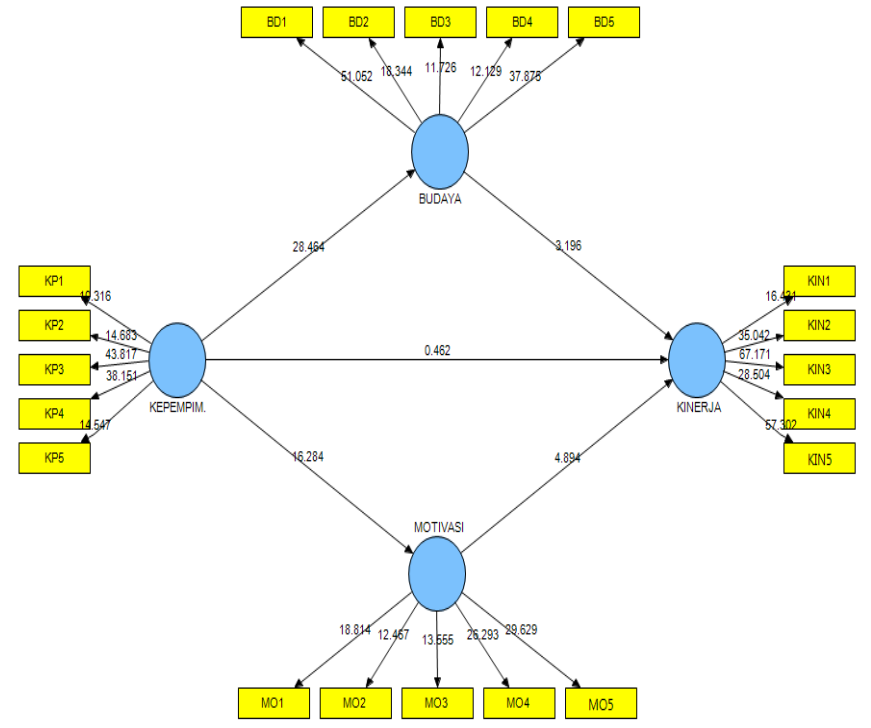

FIGURE 1. TEST RELIABILITY RESEARCH INDICATORS

Table 2 coefficient of path between variables

\begin{tabular}{|l|l|l|l|l|l|l|l|}
\hline & $\begin{array}{l}\text { Original } \\
\text { Sample } \\
(\mathrm{O})\end{array}$ & $\begin{array}{l}\text { Sample } \\
\text { Mean (M) }\end{array}$ & $\begin{array}{l}\text { Standard } \\
\text { Deviation } \\
\text { (STDEV) }\end{array}$ & $\begin{array}{l}\text { Standard } \\
\text { Error } \\
\text { (STERR) }\end{array}$ & $\begin{array}{l}\text { T } \\
\text { Statistics } \\
(\mid \mathrm{O} / \mathrm{STE} \\
\mathrm{RR} \mid)\end{array}$ & $\begin{array}{l}\text { SIG } \\
\mathrm{P}\end{array}$ & Hipotesis \\
\hline $\begin{array}{l}\text { Culture-> } \\
\text { Performance }\end{array}$ & 0.479831 & 0.466862 & 0.150145 & 0.150145 & 3.195779 & $\begin{array}{l}0.0 \\
0\end{array}$ & Accepted \\
\hline $\begin{array}{l}\text { Leadership-> } \\
\text { Culture }\end{array}$ & 0.836486 & 0.837439 & 0.029388 & 0.029388 & $\begin{array}{l}28.46388 \\
2\end{array}$ & $\begin{array}{l}0.0 \\
0\end{array}$ & Accepted \\
\hline $\begin{array}{l}\text { Leadership-> } \\
\text { Performance }\end{array}$ & $\mathbf{0 . 0 9 2 2 6 4}$ & $\mathbf{0 . 1 0 9 8 3 6}$ & $\mathbf{0 . 1 9 9 5 5 3}$ & $\mathbf{0 . 1 9 9 5 5 3}$ & $\mathbf{0 . 4 6 2 3 5 4}$ & $\begin{array}{l}\mathbf{0 . 6} \\
\mathbf{4}\end{array}$ & Reject \\
\hline $\begin{array}{l}\text { Leadership-> } \\
\text { Motivation }\end{array}$ & 0.652308 & 0.654445 & 0.040059 & 0.040059 & $\begin{array}{l}16.28384 \\
2\end{array}$ & $\begin{array}{l}0.0 \\
0\end{array}$ & Accepted \\
\hline $\begin{array}{l}\text { Motivation-> } \\
\text { Performance }\end{array}$ & 0.401858 & 0.398115 & 0.082117 & 0.082117 & 4.893699 & $\begin{array}{l}0.0 \\
0\end{array}$ & Accepted \\
\hline
\end{tabular}

\section{Hypothesis 1. The Influence of Leadershipon Performance}

The result of inner model estimation for direct influence between leadership to performance shows coefficient value of lane of 0.0922 , t-statistics of 0.462 and Sig value of 0.64 (exceeding 0.05). These statistical results prove that no convincingly proven there is a direct influence between leadership on performance. Therefore, the research hypothesis which states there is a significant influence between leadership on performance is not acceptable.

\section{Hypothesis 2. The Influence of Leadership on Organizational Culture}

The result of inner model estimation for direct influence between leadership to culture shows the value of path coefficient of 0.836486 , t-statistics of 28,463 and Sig value of 0.00 . This statistical result proves that there is a positive and significant influence between leadership on culture. Therefore,the research hypothesis which states there is a significant influence between leadership on culture is acceptable. 


\section{Hypothesis 3. The Influence of Leadership on Motivation}

Result of inner model estimation for direct influence between leadership to motivation show coefficient value of path equal to 0,652 , t-statistic equal to 16.283 and $\mathrm{Sig}$ value equal to 0.00 . The results of this statistic proves that there is a positive and significant influence between leadership on motivation. Therefore, the research hypothesis which states there is a significant influence between leadership on motivation is acceptable.

\section{Hypothesis 4. The Influence of Culture on Performance}

Result of inner model estimation for direct influence between culture to performance shows coefficient value of path equal to 0,479 , t-statistic equal to 3,195 and Sig value equal to 0.00 . The results of this statistic proves that there is a positive and significant influence between the culture on performance. Therefore, the research hypothesis which states there is significant influence between culture on performance can be accepted.

\section{Hypothesis 5. The Influence of Motivation on Performance}

Result of inner model estimation for direct influence between motivation to performance shows coefficient value of path equal to 0401, t-statistic equal to 4,893 and Sig value equal to 0.00. The results of this statistic show that there is a positive influence between the motivation on performance. Therefore, the research hypothesis which states there is a significant influence between the motivation on performance is acceptable.

\section{Discussion}

\section{Leadership does not Influence toward Employee Performance}

Leadership does not directly influence the performance of employees, this result means that whoever leader in the Regional Office of Investment and Integrated Service Pasuruan District and Regional Finance Agency Pasuruan have no direct influence on the employee performance.

Leadership is a very important factor to influence the achievement of the organization because leadership is the main activity with the achievement of organizational goals. In general, leadership is defined as a process affecting the activities of individuals or groups to achieve goals in certain situations (Indriyo, 1997: 128)

From the statement of Indriyo (1997) and the results of the above research, the leadership within the Regional Office of Investment and Integrated Service Pasuruan District and Regional Finance Agency of Pasuruan must have different ways to influence the performance of employees, because to obtain employee performance desired by the leader cannot be done directly.

The results of this study are consistent with research conducted by Susanto (2010). However, there are differentresearch ever conducted by Brury (2016), Brahmasari (2008), Indriani (2012), Guterres, Nelson, et al (2014).

\section{Leadership Positive and Significant Influence on Organizational Culture}

Leadership has a positive and significant influence on organizational culture, which means leadership can affect organizational culture. Good leadership will create a culture within the organization in the Environment Office of Investment and Integrated Services Pasuruan District and Regional Finance Agency Pasuruan become better and more.

Organizational culture is a philosophy that underlies organizational policies, rules of the association, and the feelings or climate brought about by the physical preparation of the organization (Vecchio, 1995). Good leadership should be able to enter and engage within the organizational culture so that it can be achieved according to the goals and desires that are expected through the implementation of organizational culture that continues to be better.

The results of this study are consistent with research conducted by Hulmansyah, Huda \& Bayu (2016), Guterres (2014)

\section{Leadership Positive and Significant Influence on Motivation}

Leadership has a positive and significant impact on motivation, which means that leadership has an influence on the low of work motivation in Lampung District Integrated Service and Service Environment and Pasuruan District Finance Agency.

Motivation is an effort undertaken by an organization to know and improve the workforce of a worker so that they behave as they do in the organizations of George and Jones (2002). Good leadership will motivate employees to work better.

The results of this study are consistent with research conducted by Reni (2015), Ningsih (2016), Guterres (2014)

\section{Leadership Positive and Significant Influence on Employee Performance through Organizational Culture}

Leadership positive and significant influence on the performance of employees through organizational culture, which means that performance can be influenced by 
leadership if the leadership influences the organizational culture because the organizational culture directly influence the performance of employees in the Regional Office of Investment and Integrated Service Pasuruan District and Regional Finance Agency Pasuruan. Whereas in the first discussion, leadership research results have no effect on performance.

Good leadership should be able to engage in the application of organizational culture so that employee performance can be controlled in accordance with the goals and expectations of the leadership. The better the leadership the better the implementation of organizational culture so that the performance of employees will increase. On the other hand, bad leadership leads the culture in the organization to be bad and the employee performance will decrease as well.

The results of this study are consistent with research conducted by Brury (2016), Brahmasari (2008), Marliana (2011), Guterres (2014). But unlike Susanto's research (2010)

\section{Leadership Positive and Significant Influence on Employee Performance through Motivation}

Leadership has a positive and significant impact on employee performance through motivation, which means that performance can be influenced by leadership if leadership influence work motivation because motivation has direct effect to employee performance in Lampung District Pasuruan Regency and Regional Government Financial Service. Whereas in the first discussion, leadership research results have no effect on performance.

Good leadership should be able to motivate employees to work. The better the leadership then generate a high work motivation so that the performance of employees will increase. Similarly, vice versa, poor leadership results in low work motivation so that employee performance will decrease.

The results of this study are consistent with research conducted by Susanto (2010), Brury (2016), Brahmasari (2008), Marliana (2011), Guterres (2014).

\section{CONCLUSIONS AND SUGGESTIONS}

\section{Conclusion}

Based on the results of the research analysis that has been described in the previous chapter, it can be taken some conclusions that can answer the formulation of research problems as follows: leadership has a positive and significant influence on organizational culture and motivation, which means leadership can directly influence organizational culture and work motivation, same with Hulmansyah, Huda \& Bayu (2016), Guterres (2014), Reni (2015), Ningsih (2016), Guterres (2014) . However, leadership does not influence the performance of employees, which means that whoever the leader does not directly influence the performance of employees, consistent with research conducted by Susanto (2010). But, different research result ever conducted by Brury (2016), Brahmasari (2008), Indriani (2012), Guterres, Nelson, et al (2014).
So the next conclusion of leadership has a positive and significant impact on employee performance through organizational culture and motivation, which means performance can be influenced by leadership if the leadership influence the motivation of work because the motivation directly influences the performance of employees. The results of this study are consistent with research conducted by Brury (2016), Brahmasari (2008), Marliana (2011), Guterres (2014).

\section{Suggestion}

Based on the results of the research and the conclusion above, this research can give suggestion is: Leader who served at Local Government Organization must have the ability to influence organizational culture better and motivate employees to a higher level so that employee perform better according to aim expected by the leadership. Organizational culture and performance motivation have an equally strong influence on employee performance, so the organization should continue to create an organizational culture and employee motivation to be better for the organization to obtain continuous improvement of employee performance as expected by the organization.

From this research, furthermore expected to be further developed this research model by adding avariable of commitment and satisfaction of society. Because the objectives of the current and future Government Organizations are public servants. States Civil Apparatus is required to continuously improve services to the community and of course, in the performance of serving the community, there is a commitment and prevailing policies.

\section{REFERENCES}

[1]. As'ad, Moh., 1999. Series of Human Resource Sciences, Liberly, Yogyakarta.

[2]. Armstrong, Machael, 2004. Performance Management, Tugu Publisher, Yogyakarta.

[3]. Bernadin, H. John, and Joyce E. A. Russel, 1993. Human Resource Management: An Experential Approach, Singapore: Mc. Graw Hill, Inc.

[4]. Brury, Monce, 2016. Influence Leadership, Organizational Culture, Work Motivation And Job Satisfaction Of Employee Performance At Sorong Sorong Office, Journal of Business Research and Management Vol. 4 No. 1.

[5]. Brahmasari Ida Ayu, Agus Suprayetno, 2008. The Influence of Work Motivation, Leadership and Organizational Culture on Employee Satisfaction with Impact on Company Performance (Case Study at PT Pei Hai International Wiratama Indonesia), Journal of Management and Entrepreneurship, Vol.10, No. 2, Surabaya.

[6]. Dessler, Gary, 2004. Human resources Management, 10th Edition, Prentice Hall.

[7]. Dharma, Surya, 1995. Improving Human Resource Competence through Learning Organizations, In Budi W. Soetjipto (2006), Developing Potential Human Resources, Faculty of Economics, University of Indonesia, Jakarta. 
[8]. Djokosantoso, Moeljono, 2005.Organizational Culture In Challenge.PT. Elex Media Komputindo, Jakarta.

[9]. DuBrin Andrew J., 2005. Leadership (Translation), Motivation Factor on Employee Work Performance at Perhutani Office Unit II Surabaya, Jurnal Fakultas Ekonomi Universitas Brawijaya Malang.

[10]. George, Jennifer M. and Gareth R. Jones, 2002. Understanding and Managing Organizational Behavior, Perason - Prentice Hall, New Jersey.

[11]. Guterres, Nelso, et al, 2014. The Influence of Leadership on Organizational Culture, Work Motivation and Employee Performance of Timor Leste Presidential Office, E-Journal of Economics and Business Udayana University, Vol. 3 No. 11, 639649.

[12]. Hulmansyah, et al., 2016. Analysis of the Influence of Leadership on Organizational Culture, Organizational Commitment and Employee Performance of Bank Syariah Mandiri in Jakarta, Journal of Economics and Business Aseanomics (JEBA), Vol. 1, No. 1.

[13]. Igalens, J and Rousseli, P., 1999. A Sutdy of Relationships between Compensation Package, Work Motivation and Job Satisfaction, Journal of Organizational Behavior Vol. 20, pp 1003-1025.

[14]. Indriani, Etty dan Waluyo, Hari, 2012. The Influence of Leadership and Organizational Culture on Performance of Civil Servants in the Regional Secretariat of Karanganyar Regency with Organizational Commitment as Intervening.Journal STIE AUB. Surakarta.

[15]. Indriyo, I. N. S, Gitosudarmo, 1997. Basic Principles of Management. BPFE. Yogyakarta.

[16]. Lawer, E. E., 1994. Motivation in Work Organizations, Jossey-Bass, San Francisco.

[17]. Mahsun, M., 2006. Public Sector Performance Measurement. BPFE Yogyakarta. Yogyakarta.

[18]. Marliana, B., Winanti, 2011. The Influence of Organizational Culture and Motivation of Employee Performance At PT. Atri Distribution, Profit.is.unikom.ac.id.

[19]. Mulyadi, Deddy, 2002. Expecting Optimal Public Service, People's Mind Cyber Media.
[20]. Nimran Umar, 2004. Organizational Behavior, Third Printing, CV. Citra Media, Surabaya.

[21]. Ningsih, Anum, 2016. The Influence of Leadership on Employee Motivation at PDAM Kota Madiun, Jurnal Ilmiah Ekonomi dan Learning, Vol. 4, No. 2 .

[22]. Reni, 2015. The Effect of Leadership on Employee Motivation at UD. Surya Phone in Samarinda, E Journal of Business Administration Science, Vol. 3, No. 4, 966-978.

[23]. Robbinss Stephen P, 1996. Organizational Behavior (Translations) Volume 2, Seventh Edition, PT. Bhuana Popular Science, Jakarta.

[24]. Siagian Sondang P., 2002. Tips to Increase Work Productivity, First Printing, PT. Rineka Cipta, Jakarta.

[25]. Singarimbun, Masri and Effendi, Sofian, 2008. Research Methods Surveys, Pustaka, Jakarta.

[26]. Sri Budi Cantika Yuli, 2005. Human Resource Management, UMM Press, Malang.

[27]. Sulistiyani, Ambar Teguh, and Rosidah, 2003. Human Resource Management Concepts, Theory and Development in the Context of Public Organization, Graha Ilmu, Yogyakarta.

[28]. Susanto Heri, Nuraini Aisyiah, 2010. Analysis of the Influence of Leadership and Work Culture With Motivation as Intervening Variable to Employee Performance in Land Affairs Office of Kebumen Regency, Journal of Magistra No. 74 Th. XXII December 2010, ISSN 0215-9511, 2010.

[29]. Tika, H. Moh. Pabundu, 2006. Organizational Culture and Corporate Performance Improvement Corporate Performance, First Printing, PT. Bhuni Aksara, Jakarta.

[30]. Timpe, Dale A., 1987. The Art and Science of Business Management, Motivation of Personnel, KEND Publishing, Inc., New York.

[31]. Vecchio, Robert P., 1995. Organizational Behavior, Harcout Brace \& Company, Orlando.

[32]. Vroom, V., 1964. Work and Motivation, Wiley, New York, NY.

[33]. Wibowo (2010). Performance Management, Rajawali Press, Jakarta.

[34]. Wirawan, 2007. Culture and Organizational Climate, Salemba Four, Jakarta. 